\title{
Self and Other in the Communicative Space of the Global World
}

\author{
Olga Chistyakova \\ Faculty of Humanities and Social Sciences \\ Department of Social Philosophy \\ Peoples' Friendship University of Russia (RUDN University) \\ 6 Miklukho-Maklaya Street, Moscow, 117198, Russian Federation \\ E-Mail: olgachis@yandex.ru
}

\begin{abstract}
The author presents the philosophical analysis of Self-Other relationship in intercultural and interreligious communications in the globalizing world. Special attention is paid to the semantic clarification of the processes of alienation and simultaneous mutual influence, strangification in a dichotomous interaction of Self and Other, Self and many Others in the postmodern era. The author offers in religious communications a consideration of relationship Self and the Other, where the Other is God from a philosophical-anthropological standpoint, intercultural dialogue and pluralistic approach to understanding religion.
\end{abstract}

Keywords-Intercultural and interreligious communications; Self/Other relationship; Self and God dichotomy; God as the Other; alienation; postmodernity; secularity; post-secular society; Patristics; philosophical anthropology; phenomenology

\section{INTRODUCTION}

The problem of the dichotomous Self and Other relationship in philosophy is all that is and ever will be as long as there's mankind. This is especially true in the globalization processes and transformations happening in societies in their transition from an era of late modernity to postmodernity. The urgency stems largely from the change in the status and position of an individual in the social dynamics of postmodernity, possibilities for subject's identification in the diversity of cultures, religions, ethnic groups, gender, technological and communicative differences of the postmodern world. It should be particularly noted that postmodern changes affect all spheres of social life - economic, political, social, cultural, religious, international. In connection with the changes in the social institutions, occurs a transformation of a person, his relations to society, to other people, and the state. Postmodern people are radically different from the people of modernity and even late modernity.

This paper was financially supported by the Ministry of Education and Science of the Russian Federation on the program to improve the

competitiveness of Peoples' Friendship University (RUDN University) among the world's leading research and education centers in the 2016-2020 (The Agreement number 02.A03.21.0008).
A modernity individual is an immanent "product" of his own time with the emerging conceptual justifications and narratives, while a postmodern individual bears his own imprint of the history and radically changed the condition of society. The transformation dynamics from modernity to postmodernity is a transition to a society having qualitatively different grounds and characteristics in comparison to the previous ones. Deep and accelerating transformations have affected the very nature of an individual: a postmodern individual differs significantly from the modern version of him» [1, P. 660].

\section{POSTMODERNITY: US AND OTHERS}

In postmodern society, the very concept and role of the Other (which can be understood as the other person, social group, ethnocultural or religious community, and so on) are largely displaced from actual human interaction. The place of the Other is occupied by technology, computers, social networks. In fact, the emerging in postmodernity unreal reality phenomenon, associated with information technology and mediatization of society, is starting to perform a substitutive function of the Other in relation to the category Us / Self. However, there is a process of leveling the spiritual realm, forcing out the very possibility of empathy, love, and compassion happening in parallel to the virtualization of social space, accompanied by the invasion of the simulative illusory world. After all, it's just impossible to sympathize with the computer, as the actual computer is "artless" (J. Baudrillard), devoid of sensual existential qualities. Yet, a machine, the computer often becomes the Other, through which a modern individual communicates and identifies his socio-cultural foundation.

The postmodern era is radically different in an anthropological sense from the era of modernity or even late modernity. The dynamics of the society of the $21^{\text {st }}$ century is so rapid, so exposed to digital media, that there's a new philosophical-anthropological typology of a "digital human" with a trend of dissolution of the unique personality traits and unification of the individuality. With the formation of the so-called "network" society, happens an essential transformation of the ongoing communications, based on mediatized unreal reality, being constantly created and 
reproduced (N. Luhmann) [2], perceived as objective and true. A society is turning into a "spectacle-like" society (R. Debray), where sociality is being dissolved in a constantly circulated information flows, and an individual is displaced from the objective relations regarding any activities. In media communications under such circumstances to the fore come social myths, that are being constantly produced and broadcasted by mass media and thus play a great role in shaping the public consciousness [3]. Individuality and uniqueness of a person are lost, and the spirituality is expelled to a background.

However, despite the obvious post-secular processes of postmodernity, "religion... inevitably takes the field left free - a personal space of a modern human, who has lost footing and is forced to obey both external and internal factors of the fleeting existence" [4; P. 117].

The Israeli philosopher Martin Buber, describing the culture of the last century, referred to it as "disadvantaged", unsettled, godforsaken. In this era, the feelings of loneliness, insecurity, and helplessness are being aggravated, what cause the thinkers to refer to the social and anthropological issues.

Postmodernity, in our opinion, is to some extent returning a society to the same incarnations, described by $\mathrm{M}$. Buber, but only in a more concentrated form. A person is found in a "kind of homelessness" situation in a rapidly changing world with the accelerated flow of social time, dehumanization of social life, "deterritorialization" of space and culture. However, a person is a person with his own inner world and the desire of communications in any given era.

\section{SELF AND OTHER IN INTERCULTURAL COMMUNICATIONS OF A GLOBAL WORLD}

Globalization processes of our contemporary epoch suppose the implementation of intercultural communications on a global scale. Therefore, interaction and dialogue with others - representatives of the other ethnic cultures, confessions, denominations, social groups - are impossible in the case of self-restraint. The global world presupposes the openness of societies and everyone to the Other society and the Other person. We're just "doomed" to the mutual enrichment of knowledge, experience, culture, talent and scientific data. The inner world of the subject is filled with the realities and values of the other cultures and societies, that, while being individualized, transform into self, original or alien, untouchable. Since communication in the globalizing world has the intercultural nature, then they will always inscribe the otherness, the possibility of rejection. The Russian philosopher P.K. Grechko notes in this regard: "... it is obvious, that communication takes place only when there are differences; human communication is a dialogue of differences. When the representatives of the other cultures enter the communication, the question of differences doesn't arise - the differences are phenomenally expressed and empirically given. The communicants are not just the others but also Alien to each other. It's tougher to see the Others among their own, i.e. those belonging to the same culture... our Others are designed to develop, generate universal of (one) culture, whereas the other Others develop and generate cross-cultural universals" [5; P. 120]. The communicative space of postmodernity is polyculture because globalization brings cultural, ethnical, and religious diversity. In this variety, a person perceives himself in a process of perception of the Others, often unfamiliar and alien to him. The Others may significantly change the views, inner life, personal Self of an individual, encountering the strangers. Sometimes we encounter people, whose influence is so great, that we feel alienation from ourselves and feel exposure to their magic power and will. We are trying to comprehend the essence of the Others but also transfer them our beliefs, feelings, thoughts, and knowledge. The process of mutual understanding of the essence of human nature was called the simultaneous identification and alienation of Self and the Other (strangification from the English stranger) by the representatives of phenomenology. The phenomenologists E. Husserl, E. Levinas, postmodernists G. Deleuze and J. Derrida shared the idea of mutual influence in the dichotomy Self and Other.

They appeal to the Self-Other opposition, their differences, and specific characteristic. In order to learn the world and reality in-depth, we need to know the personal Ego, the essence of each person as the Stranger (or the Other). The Other is a warrant of my Self, a real person, at a meeting with whom Self either changes itself or vanishes.

Jean-Paul Sartre, underlining the meaningfulness of "The Stranger" by A. Camus, stressed the real existence of a human with relation with the Stranger in this terrestrial world and awareness of a human being like an objective process. He wrote: "For Camus... the tragedy of human existence lies in the absence of any transcendence... He is not concerned, then, with arranging words so as to suggest an inhuman, indecipherable order; the inhuman is merely the disorderly the mechanical" [6; P. 88].

The absurd man, who knows only the good things of this world, can comprehend the Stranger (the Other in our context) in the terms of humanity. Nevertheless, Camus pointed out that the Stranger always remains silent. Why? Sartre did not shed the light on this thesis. He just stressed the classical character of the Camus' book, "a clearly orchestrated work, composed about, and against, the absurd".

We only can imagine what "the silence" of the Stranger might mean. Possibly, it's a metaphor for the Other, coming from a different culture, religion, society, and even from different discourse. The Other/Stranger feels his "Otherness" and would rather be unknowing, unrealized, keeping his own environment and cultural context [7].

It should be emphasized that in the period of globalization the process of permeating of Self and Other (as well as their possible alienation) is real and objective, filled with the specifics of their meeting. If we want to comprehend our own nature, we must penetrate deeply into the essence of the Others, those strangers, coming and leaving us. One needs to understand their intentions, cultural and religious particularities, the reasons for their disregard (or perception) by people, who are standalone, not with them. At the same time, it is a process of self-knowledge and self- 
realization of own Self through acceptance and understanding of the alien cultural values, religious and moral norms. The Other is an exception to the rule but simultaneously assumes the traditions, norms, and rules, existing in the receiving society.

The relation to the Other is particular, not common. The Stranger (the Other) has been changing in each moment of his life and I become the Stranger for myself while my Self is being in connection with him/them. The effect of the Other in relation to myself changes me and may seem quite radical. This is a developing process of mutual enrichment and awareness of each other, of reciprocal alternation, of a practice of having a deal with the differences of the Other (religious, cultural, behavioral, mental and so on).

Interesting reflection of intercultural interaction in the Self / Other framework is offered by the Canadian philosopher of Chinese origin Vincent Shen. He proposes to examine the process from the perspective of modern-day reality but with the use of traditional Confucian concepts of Ren (benevolence, humanity) and Shu (wisdom, mind, knowledge).

He replaces the idea of "the Other" of the French postmodernists and phenomenologists with the idea of "many Others". He explained that the "many Others" notion is preferable due to its focus on the concrete ontological context in which we are born, grow up and develop. We live among the many others and have to accept them into our lives and the idea "... of many Others is more realistic and clear than Levinas' concept of "tiers parts", which means only "the Other of the Other"» [8; P. 7].

From V. Shen's standpoint, the Confucian concepts of Ren and Shu reflect the greatest extent the understanding of the Others on ontological and moral planes. Ren sets the internal moral relations among people, starting from family and ending with the supreme power. Shu, being a special implementation of Ren, expands the horizons and appeals to everything, that could be above and beyond an individual, family, society, state and allows in reaching the Celestial Empire. Shu is being often interpreted as a thought form, meaning the use of Self for moral relation to the Others. V. Shen believes this concept can be explained in the modern discourse of the process of interaction and alienation of Self and Other with the simultaneous translation of this relationship to the other people in the spheres of religious, moral, and social existence [9]. The main thing there is reciprocity and consistency, which are inevitable in the era of globalization.

Intercultural dialogue with the Others - the representatives of the other ethnic groups, religions, civic nations - is incredibly relevant today, but it also can occur if each person (Self) makes a step outward, beyond his selfrestraint and self-awareness, to meet the Other, to comprehend and share the features, which ultimately leads to a mutual enrichment of knowledge, values, inner qualities, religious and cultural life, etc.

In our contemporary cultures, there is a fundamental acute problem of Self / Other relations, since there's some de-humanization of public space [10]. Nowadays, people are spiritually devastated primarily because of the lack of attention and empathy of other people, sympathy, and understanding of the Other, the only person, one is willing to let into the life and make him the center of existence. Therefore, the problem of Self / Other relationship emerges once again in contemporary cultures. A postmodern individual is acutely aware of the need to return the Other in the philosophical and cultural meanings (including when the Other means God). In a global world, embraced with the postmodern processes, there is a constant need for renewal of a spiritual and socio-cultural life in which the leading position will be occupied by the Other as a center of attraction and attention of social groups, society, and the individuals.

\section{INTERCULTURAL DIALOGUE AND RELIGIOUS EXPERIENCE OF AN INDIVIDUAL (SELF) MEETING THE OTHER} $(G O D)$

The postmodern society is often defined by the philosophers and theologians as a post-secular society. It would seem, that in pluralistic post-secular societies, overtaken by the transformations of the institutions of the late modernity, religion, faith, and sacred feelings of the actors should inevitably dissolve and disappear in the background of the secularization of life. However, we evidence the opposite process, in parallel with the growing secularization, there is a trend of actualization of religion and creed. The forming social institutions, communities, and groups of people do not exclude the existence and influence of theology, religious diversity and the desire of modern men to a religious identity along with the cultural and civic ones.

In the dynamics of the transformations of the $21^{\text {st }}$ century, the thinkers (particularly of the West) begin to frequently use the concept of God, interpreting it and even creating the new typological forms of theology and religious discourse. "It turns out, that post-secular world no less than the former one requires the interpretation of God and the attitude of a person, rationalization of human interaction and church, association of the possibilities for the activities of ecclesiastic organizations and associations in the social sphere of public life" [11; P. 45].

Under these circumstances, the role of traditional religions is being actualized, as they are very important to a personal existential experience. Religion in the modern secular or post-secular world is turning into one of the sources of self-identity, and in this respect not only offers the subject the idea of the Other but also outlines the solutions to the problems of Self / Other relations. In this respect, the Other is a person of not only the other culture or social environment but also of the other understanding of God.

In the religious worldview, the Other is God for a human. The Slovakian philosopher P. Dancak considers this ratio the following way: "The God is not bound to any place, he is present everywhere. Here we see God from the perspective I and You and not from the perspective of space. This fundamental attribute of $G o d-E l$ remained as a principal pillar of a faith of the New Testament. The forefathers did 
not just choose any power, but they chose the one being above everything" [12; P. 679].

From the philosophical-religious point of view on the ratio Self / God, the very concept of God as the Other means the variety of manifestations of the religious consideration of the Absolution, i.e. the perfect phenomenon, which in the views of people makes up for the shortcomings of the real world and teaches people a tolerant and peaceful attitude towards each other. By appealing to the faith and religious rituals, an individual of a post-secular environment somewhat weakens the severity of external and internal crises, that accompany his life. Therefore, in our view, the more secularized the society, the more attention is required to the religious sphere of life, the greater degree of rationality we should pay to religion, the religious identity of individuals. This is true not only for Russia but also for the West.

Let us refer to the opinion of the contemporary Polish Professor of sociology and media L. Dyczewski, who notes that the Western world experiences the evident "crisis of God". In this regard, he suggests talking about God in a less doctrinal, but in a more existential way in order to create new forms of culture, art, and education for more interaction and openness [13]. In fact, the philosopher speaks about the "lack of God" in a secular society, as without the idea of God as the Other, a person cannot be deeply comprehended.

Secularity is in a way a developed form of religion. Whatever character a secular society has, people will always "seek God", the Other, who will help to find and realize self in rapid transformations of the postmodernity and the disorder, often loss of the meaning of life, that accompanies a person in these conditions.

It seems to us, that religion (in the broad philosophical sense) helps to overcome the alienation of a human/community from the Other / Others as a possible result of their interaction. The idea of religious Absolution is aimed per se at bringing people together. Due to the religious communications, people overcome intercultural and behavioral differences, misunderstandings, alienation. The prominent Spanish philosopher of the late $19^{\text {th }}-$ early $20^{\text {th }}$ centuries D. Miguel de Unamuno pointed out that the process of self-realization requires the profound comprehension of God. God is an idea that helps to universalize the world and to understand ourselves. God is the Other, without whom an individual is not able to have knowledge of Self. Without an understanding of the Other existence, its otherness, there can't be a human consciousness, and without the comprehension (faith) of a human, there can't be an understanding of God. God pervades the material world and brings together two worlds the sensual and the Divine (Self and the Other) ones - into a whole ontological concept of love. Love is the foundation for Self and the Other. "Love is a contradiction if there is no God" [14; P. 81].

Thus, according to M. Unamuno, life is consciousness in its connecting with God. God pertains to the ambit of the life and human beings can understand "the God of Unamuno" arriving from the life, feels, suffers, pity, loves, and desires, but not from reason or logic. So, everything that exists out of God, lacks consciousness and vice versa. In the context of existentialism, Unamuno has explained God as human's personal response to Him. The process of personalization demands a notion of God for conceiving himself/herself. For Unamuno, God is an idea that helps a human to universalize the world and understand self. God is the Other for an individual but without Him, nobody can possess knowledge of Self. Without the Otherness, there can't be consciousness and without consciousness can't be the Other. God permeates the life of the terrestrial world and combines the two worlds of the Selfness and the Otherness into one ontological notion of love. Love is a fundament for myself and the Other. "And we create God - that is to say, God creates Himself in us by compassion, by love. To believe in God is to love Him, and in our love to fear Him; and we begin by loving Him even before knowing Him, and by loving Him we come at last to see and discover Him in all things" [15; P. 96].

We are absolutely positive that religion allows overcoming an estrangement of one person from another. The idea of God (independent from kind of creed) has been uniting people since the origin of world's religions. "Due to communication with God and human's intention of reaching the spiritual presence of God in a personal life people are overwhelming cross-cultural problems, misunderstandings and finally are able to achieve unity and reciprocity" [16; P. 663].

Again, we would like to describe it using historical approach. In this context, a special value of the Self / Other (God) relationship is found in the early Christian Patristics legacy. If we scratch open the works of the Holy Fathers of the $4^{\text {th }}-7^{\text {th }}$ centuries, we see that the essence of these works lies precisely in anthropology. Till recently the Patristics works were evaluated only from the theology's point of view, yet the philosophical-anthropological meaning of the Holy Fathers' teachings is still hidden from us and is not yet manifested in contemporary culture. These texts are rational in their nature because they show how to combine social and anthropological, theological and mundane. The texts from the depth of the centuries open a path, the golden mean, between faith and unbelief, about which wrote J. Habermas, himself unchurched.

The peculiarity of human / God relations is being discussed in the Christian Patristic literature since the period of Early Christianity. The Church Fathers underlined the idea of personal communion with the Christian Gog like an objective for each human being. It is possible to note in this sense the great creation of Saint John Climacus, also well known as John of the Ladder. He was the $7^{\text {th }}$-century Christian monk at the monastery on Mount Sinai. He wrote mostly for the monks and elaborated the concept of obtaining God via thirty steps of man's deification. The book "Ladder", written by John Climacus, described how to raise one's soul and body to God through the acquisition of ascetic virtues. It was the ladder or path of personal deification to gain the spiritual communion with the God. The twenty-ninth step was named "Love", first of all, "Love to all people". John Clumacus' followers, who were able to reach the level of "Love to people", could ascend to the final thirtieth step, 
titles "Love to God and God is love". Solely at this level, a human obtains communion, spiritual unity to God, having reached the objective (goal) of God's cognition and simultaneously personal self-cognition and self-purification.

The transformation of human nature and turn to the unity with God with the emergence of the "Other" was also described by Saint Afanasiy the Great. He writes: "The way to God isn't far from the Human, it isn't out of us, quite the contrary, it is inside us. And the starting of this way can be possibly found out personally. What is this way? - The soul of everybody and the mind inside it; because the only mind is able to contemplate and cognize the God" [17; pp. 165166]. The aforementioned idea of the Saint Father signifies the overcoming of a dualistic nature of a Human being by the unity with God of personal, individual, free and rational human's nature.

In general, the early Christian writers underlined the concurrent process of God's cognition and individual's selfcognition. It was described as the "path to self", like the process of personal self-consciousness and self-creation through the search of moral ideals, comparison of one's behavior with the Absolute morality of God, which was shown by Jesus Christ. Thus, the gradual personal ascendance to the communion with God has been radically changing a human essence, so that man becomes radically different compared to him at the very beginning of his religious quest.

Turning again to contemporary time, we would like to note that inter-religious (as cross-cultural) dialogue is very important for people of different cultural worlds. It is better for representatives of one religion to conceive the ideas of another religion through the awareness of morality and personal experience in cognition of Absolute reality of God and it would allow one to have access to God's various manifestations in religious diversity of the modern global world. The mutual enrichment is better than conflict or war. The religious communication is better than political confrontation or cross-cultural and inter-religious conflicts.

In the era of globalization, the relations among people of various faiths and religions, among various communities, must be built upon the basis of tolerance, recognition of the importance of the Other, including the other ethnic groups and creeds. P. Dancak pays special attention to this point: "The tolerance could seem that the ties between the secular and religious worlds were definitely severed. However, the religious context of tolerance has once again become apparent in today's post-secular society" [18; P. 678].

In our opinion, a postmodern individual, somewhat tired of secularization, shall lineup own existence on the basis of rational self-realization along with the ideas of Absolution: ideas of good, peace, tolerance, humanism, lack of social violence in all of its forms. For a religious person, all these concepts are enclosed in the concept of God. The absolute human values that we find in the works of the Holy Fathers express both religious and secular humanistic sense. These ideas are rational, capable of becoming a rallying point for various ethnic cultures and religions [19]. Post-secular world promotes this dialogue and even requires it. Religion in philosophical terms has an anthropological nature, it reflects the spiritual potential of each person, and therefore can serve to nurture a holistic young person, given his uniqueness and talent [20].

\section{CONCLUSION}

We are all pilgrims and strangers in the global world. We are all Others to each other and even to ourselves. Nevertheless, it is in the apprehension of the Other, each subject can understand the own life and perpetuate it, leaving the unique mark. The idea of mutual spiritual enrichment in the Self / Other relationship allows accepting the Other, to meet him in the same community-based intercultural and interreligious dialogue and common ground. Social life today requires that the Other exists in it as the center of existence, the center of culture, the center of Self, which is going to meet the Other or God.

Culture and religion in the modern world do a great communicative role [21]. Through religious and intercultural relations huge numbers of people can communicate, carry out joint projects, share their values and spiritual and moral needs and preferences. Surely, religion is a special means of communication among people, building relationship based on the creeds. (Let us emphasize once again that we are talking about traditional religions and denominations). Moreover, the churched people transmit their knowledge, information, values to the secular part of society. And it should be considered and used for good. Information, having a sacred meaning, is needed by the post-secular societies, because with the secularization disappeared something sacred in interpersonal and social relations. Therefore, the sacred meaning of the religions, the meaning of the absolute values of the Other cultures, the understanding of God of the other religions should be a bit inherent to everyone in the modern world.

\section{REFERENCES}

[1] Chistyakova O. Relationship of Self and Other in Cultural and Religious Communications // Proceedings of the 2016 3rd International Conference on Education, Language, Art and InterCultural Communication (ICELAIC 2016). Advances in Social Science, Education and Humanities Research. Paris: Atlantis Press, 2017. Volume 40. - P. 660-664

[2] Luhmann, N. The Reality of the Mass Media. M., Praxis. 2005. 256 p.

[3] Ponizovkina I.F. Social Myth in Modern Society // Proceedings of the 2016 3rd International Conference on Education, Language, Art and Inter-Cultural Communication (ICELAIC 2016). Advances in Social Science, Education and Humanities Research. Paris: Atlantis Press, 2017. Volume 40. - P. 648-653.

[4] Chistyakova O. Rationalization of Contemporary Culture and Education in the Context of Religious Resistance to Violence // Proceedings of the 2016 International Conference on Arts, Design and Contemporary Education. (ICADCE 2016). Advances in Social Science, Education and Humanities Research. Paris: Atlantis Press, 2016. Volume 64. - P. 1192-1198.

[5] Grechko Pyotr K. Onthomethodological Discource of Contemporaneity: Historical Advancement and its Challenges. Moscow: LENAND, 2015. $312 \mathrm{c}$.

[6] Sartre Jean-Paul. Existentialism and a Humanism. Yale university press. 2007. - P. 108. 
[7] Chistyakova O. Media Myth Influence on "Other" Culture Formation in Russian Society (in the Context of External Migration) // Science Almanac of Black Sea Region Countries. Rostov on/Don. № 1. 2015 г. - P. 59-64.

[8] Shen V. Confucian Altruism, Generosity and Justice: A Response to Globalization // Washington, DC. Council for Research in Values and Philosophy, CUA. 2016.

[9] Ibid.

[10] Ponizovkina I., Agibalova E. Loss of Life Purpose as a Problem of Modern Society // Proceedings of the International Conference on Contemporary Education, Social Sciences and Humanities (ICCESSH 2016). Advances in Social Science, Education and Humanities Research. Paris: Atlantis Press, 2016. - P. 657-661.

[11] Chistyakova O.V. Society and Religion in a Postsecular Age: Theoretical Approaches and Empirical Interaction // Bulletin of Peoples’ Friendship University of Russia. Series Philosophy. 2016, № 2. - P. 43-51.

[12] Dancak P. The Cristian Universalism, Globalization and Tolerance in the Thought of Joseph Ratzinger-Benedict XVI // Proceedings of the 2016 3rd International Conference on Education, Language, Art and Inter-Cultural Communication (ICELAIC 2016). Advances in Social Science, Education and Humanities Research. Paris: Atlantis Press, 2017. Volume 40. - P. 678-682.

[13] Dyczewski L. New Technologies and Styles of Evangelization // Renewing the Church in a Secular Age: Holistic Dialogue and Kenotic Vision. March 4-5, 2015. Pontificia Universita Gregoriana, Rome. A Joint Conference with Council for Research in Values and Philosophy and the Patronage of Pontifical Council for Culture. Rome, 2015.

[14] Unamuno M. Tragic sense of Life. New York, Dover Publication, INC. 2005.

[15] Ibid.

[16] Chistyakova O. Relationship of Self and Other in Cultural and Religious Communications // Proceedings of the 2016 3rd International Conference on Education, Language, Art and InterCultural Communication (ICELAIC 2016). Advances in Social Science, Education and Humanities Research. Paris: Atlantis Press, 2017. Volume 40. - P. 660-664.

[17] Afanasiy the Great. The Creations. In 2 vol. Vol. 1. - Moscow. Bogosloviye. 1994.

[18] Dancak P. The Cristian Universalism, Globalization and Tolerance in the Thought of Joseph Ratzinger-Benedict XVI // Proceedings of the 2016 3rd International Conference on Education, Language, Art and Inter-Cultural Communication (ICELAIC 2016). Advances in Social Science, Education and Humanities Research. Paris: Atlantis Press, 2017. Volume 40. - P. 678-682.

[19] Chistyakova O.V. Russian Religious Philosophy as the Basis for State Identity // Journal of Eurasian Research. 2003. Volume 2. № 1. ISSN 1538-0378. P. 13-17.

[20] Ivleva M., Bagramiants N., Ivlev V., Oseledchik M. Methodological Principles of the Study of the Philosophical Foundations of Psychological Conceptions of Giftedness//Proceedings of the 2016 3rd International Conference on Education, Language, Art and InterCultural Communication (ICELAIC 2016). Advances in Social Science, Education and Humanities Research. Paris: Atlantis Press, 2017. Volume 40. - P.48-52.

[21] Chistyakov D. Social Dimension of Media Space in the Age of Postmodernity. In the Context of Objective Knowledge Obtainment // Proceedings of the 2016 International Conference on Arts, Design and Contemporary Education. (ICADCE 2016). Advances in Social Science, Education and Humanities Research. Paris: Atlantis Press, 2016. Volume 64. - P. 297-300. 